\title{
THE ACTION OF CERTAIN BACTERIA ON PROTEINS.
}

\author{
By F. A. BAINBRIDGE, M.A., M.D., D.Sc., D.P.H. \\ (From the Lister Institute of Preventive Medicine, London.)
}

THE digestion of solidified blood-serum by certain sporing bacilli is well known, and Bienstock (1899) and Rettger have shown that $B$. putrificus and other obligate anaerobic sporing bacteria destroy protein and cause putrefactive changes. Hardly any observations have been made, however, to determine whether aerobic, non-sporing bacilli and cocci have any power to break down proteid, although it is often assumed they can do so. Rettger (1906) found that bacilli of the colon group did not set up putrefactive changes in a mixture of egg and meat protein; he made no quantitative experiments as to whether any destruction of protein took place, and Dr C. J. Martin informed me that he has for long noticed that preparations of pure proteins, when left exposed to air, did not appear to be broken down by bacteria, although moulds were able to grow in them.

In the present enquiry an attempt bas been made to ascertain whether certain aerobic organisms can break down either pure proteins, or solutions of protein in the presence of various nitrogenous extractives.

\section{METHODS.}

\section{Preparations of pure proteins.}

Three proteins were selected for examination, namely

(1) Egg-albumin ;

(2) The total coagulable protein (globulin and albumin) of horse serum : and

(3) Alkali-albumin, prepared from egg-albumin.

(1) Egg-albumin. Crystalline egg-albumin was prepared by Hopkins' method and dissolved in distilled water. The protein was 
then precipitated with anhydrous sodium sulphate at $37^{\circ} \mathrm{C}$, washed with a solution of sodium sulphate of the same sp. gr. as the filtrate, dried between sheets of blotting-paper, and redissolved in distilled water. This process was repeated many (8-10) times, until the solution was almost free from ammonia.

For the final solution, ammonia-free distilled water was used.

Most of the sodium sulphate was removed by allowing it to crystallise out at $0^{\circ} \mathrm{C}$. and by subsequent dialysis of the protein solution. The solution was finally sterilised by filtration through a Berkefeld filter, previously washed with distilled water. One obtained in this way a fairly strong $(2-5 \%)$ solution of egg-albumin which served as a stock.

(2) Serum protein. The total coagulable protein present in normal horse serum was precipitated by the addition of anhydrous sodium sulphate, the serum being warmed to $37^{\circ} \mathrm{C}$. The precipitate was washed with a solution of sodium sulphate of the same specific gravity as the filtrate, dried between sheets of blotting-paper, and redissolved in a small quantity of distilled water. This process was repeated 10-12 times until a protein solution was obtained, which was almost free from extractive nitrogen. For the final solution, ammonia-free distilled water was used; most of the sodium sulphate was removed by allowing it to crystallise out at $0^{\circ} \mathrm{C}$. and by subsequent dialysis of the protein solution for an hour.

The solution, which was yellowish in colour, was finally sterilised by filtration through a Berkefeld filter and was kept as a stock.

Two or three preparations of egg-albumin and serum-protein were made in the course of the experiments, and varied somewhat as to their relative purity.

(3) Alkali-albumin. The material used had been prepared from pure egg-albumin by Dr C. J. Martin. It was dissolved in a $0.5 \%$ sodium carbonate solution; normal hydrochloric acid was then added until a point was reached at which the protein began to be precipitated. The amount of free ammonia present in these solutions was estimated and used as an indication of their purity, since it is very difficult to remove all the free ammonia from such solutions by the precipitation method. The following figures were obtained for two samples:

(1) 1 c.c. of a stock solution of serum protein contained 0.000008 grm. $\mathrm{NH}_{3}$.

(2) 1 c.c. of a solution of alkali-albumin contained $0.000008 \mathrm{grm}$. $\mathrm{NH}_{3}$. 


\section{Preparation of media.}

For the purpose of estimating the multiplication of bacteria in solutions of pure protein, a weak solution $(0.1-0.5 \%)$ of protein was made by diluting a portion of the stock solution of protein with ammonia-free distilled water. Various salts were added and the final composition of the medium was as follows :

Protein 0.1-0.5\%.

Sodium chloride $0.5 \%$.

Sodium sulphate (approximately) $0 \cdot 1-0 \cdot 25 \%$.

$\left.\begin{array}{l}\text { Calcium chloride trace } \\ \text { Potassium phosphate trace }\end{array}\right\}$ approximately $0.1 \%$.

Sulphuric acid $\left(\frac{N}{100}\right)$ was added until the medium, which at first was distinctly alkaline, became very faintly alkaline to extremely sensitive red litmus paper. It was then sterilised by filtration through a Berkefeld filter, and put in test tubes, so that each contained roughly 5 c.c. of fluid.

For the chemical estimation of protein the media were prepared in the same way, except that stronger solutions of protein were used. Usually 20-25 c.c. of the medium were accurately measured with a sterile pipette into a number of small flasks, which after incubation at $37^{\circ} \mathrm{C}$. for two days were tested as regards their sterility. Some were kept as controls, the remainder being inoculated with various organisms from fresh agar cultures. All the flasks were incubated at $37^{\circ} \mathrm{C}$. for 7-28 days, the same time being allowed in each experiment. The amount of coagulable protein present in each flask was then estimated. The solution was poured into a small beaker, made distinctly acid to sensitive neutral litmus paper by the addition of $\frac{N}{100}$ butyric acid, and boiled for several minutes until the protein was coagulated and the supernatant fluid was perfectly clear. The coagulum was collected on a weighed filter paper, dried and weighed. In one or two experiments, the residual nitrogen was estimated by Kjeldahl's method after removal of the protein by tannic acid; and occasionally the amount of free ammonia present in the solution was determined by the vacuum distillation method. 


\section{Method of determining the multiplication of organisms.}

The test tubes containing the media were incubated at $37^{\circ} \mathrm{C}$. for 24 hours and then tested as regards their sterility. A small quantity of the organisms under examination was taken from a fresh agar culture by means of a fine platinum needle and added to the fluid in the test tubes. After half an hour, the tube was well shaken and two drops were taken from the test tube, by means of a capillary pipette, and dropped into 5 c.c. of sterile normal saline solution which was well shaken. This was called the first dilution. With the same pipette two drops were taken from the dilution and dropped into a second test tube also containing 5 c.c. of sterile saline solution, known as the second dilution. In some cases a third dilution was made in the same way. Five drops and one drop from the original medium and from each dilution were dropped into petri plates and ordinary agar plates were made, taking care to ensure a good mixture. After incubation of the plates for 24, hours, the colonies on each plate were counted. All the plating was done in duplicate. The test tubes containing the inoculated media were incubated at $37^{\circ} \mathrm{C}$. and the number of organisms present was determined from day to day by the above method.

The same pipette was used throughout the whole of the experiment, and was dried each time before and after being used as a "dropper" so that the size of the drops should be, as far as possible, uniform. As a rule five organisms were examined in each experiment, and aseptic precautions were always taken.

Other details as to the methods used are given subsequently.

The micro-organisms used in the experiments were as follows :

(1) B. coli communis, stock strain, Lister Institute.

(2) B. enteritidis Gaertner, original strain.

(3) B. typhosus Guy, stock strain, Lister Institute.

(4) B. proteus, stock strain, Lister Institute.

(5) B. pyocyaneus, stock strain, Lister Institute.

(6) Staphylococcus p. aureus, from an acute abscess.

(7) Gonococcus, from case of acute gonorrhoea.

The same strains were used throughout the whole investigation. 


\section{RESULTS.}

\section{MUltiplication of Bacteria in Media CONTAINiNg ONLY PURE PROTEIN AND SALTS.}

Visible growth rarely occurred, though a faint opalescence was occasionally observed in the case of the less pure preparations of protein.

The multiplication of the organisms (as determined by plating) was influenced by two factors, namely, the purity of the medium and the number of the organisms originally added to the medium, and the actual figures obtained in the various experiments show only a general correspondence with one another.

Even the purest preparations of the proteins contained traces of ammonia, and probably other nitrogenous extractives; and some of the organisms used, notably $B$. enteritidis Gaertner, can exist and even multiply to some extent in solutions containing the merest traces of organic material. In this enquiry it was found that, when the bacterial seeding was small, some multiplication took place in all the protein media, but when a larger bacterial seeding was made, the numbers of organisms diminished in the purest protein media, whereas some multiplication occurred in the less pure protein media.

The general results are given in Tables I-III. They show that no extensive multiplication of bacteria occurred, although the seeding was usually large, and that the organisms examined grew very little better in solutions of protein than in solutions of glucose (and salts), in ammonia-free distilled water. The power to multiply was least in the case of B. typhosus and Staphylococcus aureus. In fact cultures of these two organisms on protein media were sometimes sterile, when subcultured after incubation for a week or more.

In a number of experiments, 0.5 to $1 \%$ glucose was added to the protein media. It seemed possible that the organisms might be able to break down protein, when a readily utilisable source of energy and of carbon was present. The addition of sugar had very little influence, however, on the growth of the organisms examined, as long as the protein medium was pure. A very faintly acid reaction of the medium to sensitive red litmus paper was sometimes observed, but in other cases no difference could be detected between the inoculated and the control tubes. 
Since glucose is readily attacked by all the organisms employed, when available nitrogenous food is present, the minimal destruction of glucose (as judged by the formation of acid) in these experiments seems to show not only that the media contained very little nonproteid nitrogen, but also that very little (if any) proteid was broken down.

The fact that when comparative tests were made with the same sample of a protein medium, the number of organisms tended to become constant after a few days with either a large or small seeding (Table IV), also suggests that the organisms were living on the traces of non-protein nitrogen in the medium rather than on the protein itself. In the latter case one would expect a progressive increase in the number of organisms as more and more protein was used up, whereas, in point of fact, the number of organisms tended to decrease after three or four days. When a few drops of broth or of impure solution of albumose were added to the protein medium, all the organisms showed multiplication, and $B$. coli and $B$. enteritidis grew freely, indicating that the media contained nothing which inhibited or interfered with the growth of organisms.

\section{Media containing gelatin.}

A few observations were made with a medium containing $10 \%$ gelatin, salts and distilled water; the gelatin was not purified at all. The medium was made neutral to sensitive red litmus paper. B. proteus, B. pyocyaneus and Staphylococcus aureus grew very feebly on this medium; and although some liquefaction eventually took place, it was greatly delayed. When $1 \%$ glucose was added to the medium, Staphylococcus aureus showed very little growth, B. proteus and B. pyocyaneus grew rather more vigorously, but did not visibly liquefy the gelatin for ten days, although they liquefied control tubes of ordinary broth gelatin very rapidly.

It is probable that a medium consisting only of gelatin, salts and water, is very slowly digested by these organisms, chiefly because they grow feebly and therefore produce very little digestive enzyme. But this may not be the only factor, since the conditions which influence the activity of the extracellular proteolytic enzymes of $B$. proteus and $B$. pyocyaneus are not fully worked out; and it is not known how far an acid or alkaline reaction of the medium modifies their proteolytic power. 


\section{The aCtion of BACTERIA UPON PROTEIN, AS DETERMined BY CHEMICAL METHODS.}

The amount of coagulable protein present in protein media before and after inoculation with various organisms was estimated by the coagulation method. One or two observations were also made to determine whether the presence of bacteria in solutions of pure bacteria and salts influenced the amount of uncoagulable nitrogenous material in the solutions.

\section{(a) Pure proteins.}

When the solutions contained only pure protein and salts, none of the organisms examined were able to break down the protein. The results, given in Table $\mathrm{V}$, show that the amounts of coagulable protein in the control and inoculated flasks were the same, allowing for the experimental error of the method. Even B. proteus and B. pyocyaneus did not destroy protein when it was pure.

The observations as to the amount of non-coagulable nitrogenous material present in control and in inoculated flasks containing solutions of pure protein showed no evidence that any destruction of protein occurred in the inoculated flasks.

\section{(b) Solutions of protein and nitrogenous extractives.}

A number of experiments were made to determine the effect of adding to solutions of pure protein, either albumoses, peptone, broth or other nitrogenous material. It seemed possible that, when sufficient material was present to ensure vigorous bacterial growth, the protein might be broken down. Chemical methods alone were available for this investigation.

The substances added to the protein solutions in different experiments were the following :-

(1) Ordinary peptone broth in sufficient amount to form a $0.3 \%$ solution (medium A).

(2) An impure preparation of albumose, prepared from Witte's peptone, but still containing some extractive nitrogen (medium $\mathrm{B}$ ).

(3) Horse serum diluted and freed from coagulable protein by boiling in acid solution. The filtrate contained no coagulable protein, but gave a very faint Xantho-proteic reaction (medium C). 
(4) Horse serum freed from protein by filtration through a silica filter (Martin, C. J., 1896).

(5) Medium E. Diluted horse serum, heated to $55^{\circ} \mathrm{C}$. for half an hour to destroy complement.

Suitable amounts of sodium chloride and other salts were added to all the media, which were then neutralised and filtered through a Berkefeld filter. 20 c.c. were accurately measured into a number of sterile flasks; some of these were kept as controls, others were inoculated with various organisms. After incubation for six or more days at $37^{\circ} \mathrm{C}$. the total coagulable protein present was estimated.

The results are given in Tables VI and VII. They show that, in the presence of an adequate supply of nitrogenous food, $B$. proteus can break down protein, but that the other organisms examined do not disintegrate it-at any rate, to any appreciable extent. No constant diminution in the amount of coagulable protein occurred, and the small differences observed in individual experiments are due to the technical difficulties of the method.

Good growth occurred in all cases, and the reaction of the solutions became alkaline as compared with the controls. The degree of alkalinity was measured by noting the number of drops of $\frac{N}{10}$ butyric acid required to render the solution neutral to very sensitive red litmus paper. The degree of alkalinity of the media (after incubation) varied with the different organisms used, being greatest for B. proteus and least for Staphylococcus pyogenes aureus.

Serum-proteins are fairly sensitive to acids and alkalies, and are gradually disintegrated in a strongly alkaline solution. But the amount of alkali formed by the bacteria used in these experiments was apparently too small to cause any appreciable destruction of the protein present in the media, even when the initial reaction of the medium was slightly alkaline to sensitive litmus paper. When a mixture of serum protein and peptone broth was used, none of the coagulable protein was destroyed, whether the initial reaction of the medium was neutral or slightly alkaline.

It may be noted also that proteins themselves can act either as weak acids or as weak alkalies, and that when present in large amount (as in blood serum) must exert a considerable influence in keeping the reaction of the medium near the neutral point.

This action, on the part of proteins, is probably of importance in modifying the way in which bacteria break down non-protein nitrogenous 
substances, since it is well known that the activities of many organisms are closely dependent upon the reaction of the medium in which they are placed. The Gonococcus, for example, will grow well on ordinary agar, to which pure serum-protein or egg-albumin is added, although there is no evidence from chemical analysis to show that it can break down serum-protein. It will also grow on agar, to which is added the serum (deprived of all protein), but containing phosphates. Indeed, as Blair Martin (1910) has shown, strains of Gonococcus which fail to grow on ordinary agar will grow readily when phosphates are added.

Apparently, the Gonococcus requires for its existence and multiplication a medium of a particular degree of alkalinity, and the presence of proteins or phosphate serves to keep the reaction of the medium at a suitable point.

\section{ThE FORMATION OF INDOL FROM PURE PROTEIN.}

So far as is known, indol is formed by bacteria only from tryptophane or from proteins (or polypeptides) which contain a tryptophane radicle. Whether any bacteria, when growing in media free from a tryptophane radicle, can produce small traces of indol as a product of their own metabolism is not known. In the present enquiry, B. coli was cultivated on some media, which responded to none of the tests for a tryptophane group ; no indol could be detected in these media.

It seemed, therefore, that the formation of indol in media containing only pure protein would indicate that the indol had been formed by bacteria from the protein. The media examined were:

1. Solutions of pure egg-albumin and serum-protein.

2. These solutions with the addition of $1 \%$ urea.

The media were neutral to litmus paper and were sterilised by filtration through a Berkefeld filter. A series of test tubes containing these media were inoculated with $B$. proteus or $B$. coli communis; after incubation for 5-10 days they were tested for indol by the paradiamethylamidobenzaldehyde method. A negative reaction was obtained in all cases.

It is clear from these experiments that the organisms examined do not break down appreciable amounts of pure protein, and that $B$. coli, B. pyocyaneus, B. enteritidis and Staphylococcus aureus do not cause any gross destruction of protein, even in the presence of an adequate supply of non-protein nitrogenous food. There is, in fact, no evidence that these organisms can break down protein at all; possibly the protein 
molecule is too large to be taken up by the organisms. It is important to remember, however, that exceedingly small quantities of nitrogenous food are needed to maintain bacterial life and permit of some multiplication; and it is conceivable that the organisms examined may be able to break down very minute traces of protein, traces so minute as to escape detection by the methods employed.

\section{Conclusions.}

(1) When solutions of pure egg-albumin, serum-protein or alkalialbumin are inoculated with the organisms studied in this enquiry, the bacteria diminish in number when the seeding is large, but multiply to some extent when the seeding is small. The evidence goes to show that the multiplication observed with small seedings is due to the presence in the medium of traces of non-protein nitrogenous substances, and that the bacteria do not use protein as food.

(2) There is no chemical evidence that the organisms which have been studied are able to break down pure egg-albumin and serumprotein; but such very minute amounts of nitrogenous food suffice to maintain bacterial life that, with the methods available, one cannot be certain that the organisms did not disintegrate and use as food very small traces of protein.

(3) The organisms examined (with the exception of B. proteus) do not break down appreciable quantities of egg-albumin and serumprotein, even in the presence of sufficient non-protein nitrogenous food, to ensure vigorous bacterial growth.

I wish to acknowledge my indebtedness to $\mathrm{Dr}$ C. J. Martin for constant help and advice in the course of this enquiry. 
TABLE I.

The organism examined was B. typhosus.

The figures represent the number of organisms actually counted on the plates made in duplicate from the various dilutions of the medium.

(a) Egg-albumin.

Dilution examined

Medinm itself, 5 drops

1st dilution, 5 drops

" 1 drop

2nd dilution, 5 drops

,, 1 drop

(b) Serum-protein. Dilution examined

1st dilution, 1 drop

2nd dilution, 5 drops

3rd dilution, 5 drops

, 1 drop

\begin{tabular}{cccc} 
Uncountable & \multicolumn{4}{c}{ Period of incubation in days } \\
Un & - & - & 6 \\
243,239 & 222,190 & 626,528 & - \\
60,50 & 46,38 & 201,158 & - \\
- & - & - & 80,75 \\
- & - & - & 5,1 \\
& & - & 1,0
\end{tabular}

Too many to count $\quad 405,492 \quad 192,212$

$609,490 \quad 16,18 \quad 10,10$

$55,90 \quad 5,3 \quad 1,3$

$7,21 \quad 1,0 \quad 1,0$

1,100 


\section{TABLE II.}

The figures represent the number of organisms present in one drop of the medium, which was examined at the time of inoculation and on subsequent days.

In the case of most of the organisms, two experiments are recorded, one with a small seeding and one with a large seeding.

(a) Egg-albumin.

Organism examined

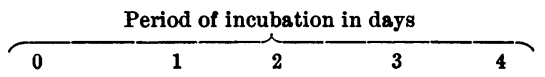

B. typhosus (1) $\quad \ldots \quad 6,025 \quad 5,150 \quad 15,150 \quad-\quad \quad-\quad 6$ days 7,500 .

$\begin{array}{llllllll} & (2) & \ldots & 56,125 & - & 20,375 & - & 14,375\end{array}$

B. coli communis (1) $\ldots \quad 11,125 \quad-\quad-\quad 35,500 \quad-\quad 6$ days 25,250 .

$\begin{array}{lllllllr}" & (2) & \ldots & 495,875 & - & 153,750 & - & 30,000 \\ \text { teritidis (1) } & \ldots & 185,625 & - & 245,625 & - & 232,500\end{array}$

" $\quad(2) \quad \ldots \quad 37,500 \quad-\quad 144,375 \quad-\quad$ - 8 days 26,250 .

(b) Serum-protein.

Organism examined

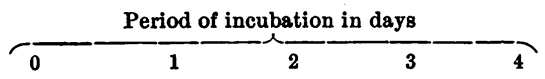
B. typhosus (1)
$\ldots 1,029,375$
31,875
18,750 - -
"
(2)
... 34,250
45,375
123,750
- 17,125 -
B. coli communis (1)
(1) $\ldots \quad 335,575$

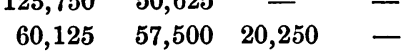
B. enteritidis
(2) $\ldots 200,000$
$20,250 \quad-$
B. proteus
.. 468,750
$288,750 \quad 264,375$
- 211,875
No indol, 7 dys.
Staphylococcus aureus (1)
.. $\quad 840,000 \quad 520,000 \quad 393,750$
(2) 228,750
$1,312,500$
161,250

",

$$
\text { , }
$$

(c) Alkali-albamin.

Organism examined

\begin{tabular}{|c|c|c|c|c|c|}
\hline B. typhosus & $\ldots$ & 150,000 & 59,250 & 32,875 & 28,875 \\
\hline B. coli communis & . & 143,750 & 一 & 153,750 & 112,500 \\
\hline B. enteritidis ... & $\ldots$ & 843,750 & - & 453,750 & 61,875 \\
\hline B. proteus & $\ldots$ & 71,000 & - & 150,000 & 60,000 \\
\hline Staphylococcus aureus & (1) & 90,000 & 59,415 & 56,250 & 一 \\
\hline , & (2) & 52,250 & 一 & 29,375 & 2,000 \\
\hline
\end{tabular}

(d) Serum-protein $+1 \%$ glucose.

\begin{tabular}{|c|c|c|c|c|c|c|}
\hline \multirow[b]{2}{*}{ Organism examined } & & \multicolumn{4}{|c|}{ Period of incubation in days } & \multirow[b]{3}{*}{15 days. No indol. } \\
\hline & & 0 & 2 & 4 & \multirow{2}{*}{15} & \\
\hline B. coli communis & $\ldots$ & 843,750 & 423,125 & 153,750 & & \\
\hline B. enteritidis ... & $\ldots$ & $1,350,000$ & $1,025,625$ & 468,750 & \multicolumn{2}{|c|}{900 (approx.) } \\
\hline B. proteus & $\ldots$ & $1,428,750$ & 480,000 & 69,375 & - & \multirow[t]{2}{*}{15 days. No indol. } \\
\hline Staphylococcus aureus & $\ldots$ & 300,000 & 205,500 & 44,500 & \multirow[t]{2}{*}{ - } & \\
\hline \multicolumn{6}{|c|}{ (e) Alkali-albumin $+1 \%$ glucose. } & \\
\hline \multicolumn{7}{|c|}{ Period of incubation in days } \\
\hline Organism examined & & \multicolumn{2}{|l|}{0} & 2 & \multirow{4}{*}{\multicolumn{2}{|c|}{$\begin{array}{l}5 \text { days, slightly acid to litmus. } \\
5 \text { days, neutral to litmus. }\end{array}$}} \\
\hline B. coli communis & $\ldots$ & 77,000 & \multicolumn{2}{|c|}{98,500} & & \\
\hline B. typhosus ... & $\ldots$ & 613,125 & \multicolumn{2}{|c|}{570,000} & & \\
\hline Staphylococcus aureus & $\ldots$ & $1,076,2$ & \multicolumn{2}{|c|}{973,125} & & \\
\hline
\end{tabular}




\section{TABLE III.}

The organism used was $B$. coli communis.

The figures represent the number of organisms present in one drop of the medium at the time of inoculation and on subsequent days.

\begin{tabular}{|c|c|c|c|c|c|c|c|c|}
\hline \multirow{2}{*}{\multicolumn{2}{|c|}{ Medium used }} & & \multicolumn{5}{|c|}{ Period of incubation in days } & \\
\hline & & $\cdot$ & 0 & 1 & 2 & 3 & 4 & \\
\hline (1) & Normal saline soluti & & 12,300 & - & - & 425 & - & \\
\hline (2) & $1 \%$ glucose + salts & $\ldots$ & 33,875 & 221,250 & - & 119,250 & - & \\
\hline (3) & Egg-albumin $(a)$ & $\ldots$ & 11,125 & 一 & 一 & 35,750 & - & 6 days, 25,000 . \\
\hline (4) & (b) & $\ldots$ & 496,875 & - & - & 153,750 & - & 6 days, 30,000. \\
\hline (5) & Serum-protein $(a)$ & $\cdots$ & 330,000 & 123,750 & 48,700 & - & 一 & \\
\hline (6) & (b) & $\ldots$ & 71,375 & 55,125 & 一 & 30,625 & - & 8 days. Noindol. \\
\hline (7) & Serum-prot. + glucos & & 843,750 & - & 423,125 & - & 153,750 & \\
\hline (8) & Alkali-albumin & $\ldots$ & 143,750 & - & 153,750 & - & 一 & 11 days, 112,500 . \\
\hline (9) & Alk.-alb. +glucose & $\ldots$ & 20,000 & - & 250,000 & - & 一 & \\
\hline
\end{tabular}

\section{TABLE IV.}

The medium used was pure serum-protein. The organism examined was $B$. coli communis. The figures represent the number of organisms actually counted on the plates.

I. Small seeding.

Dilution counted

1st dilution, 1 drop

2nd dilution, 5 drops

\begin{tabular}{crr}
\multicolumn{4}{c}{ Period of incubation in days } \\
\hline 13 & 1 & 3 \\
1 & 1212 & 810 \\
1 & 69 & 61 \\
10 & 12
\end{tabular}

9 days. No indol.

, 1 drop

II. Large seeding.

1st dilution, 1 drop

2nd dilution, 5 drops

1 drop

10

$\begin{array}{cr}1000 \text { (approx.) } & 1015 \\ 97 & 103 \\ 25 & 28\end{array}$

9 days. No indol. 


\section{TABLE V.}

The action of bacteria upon solutions of pure protein and salts.

In all cases the initial reaction of the medium was as nearly as possible neutral. Control experiments were always made.

The figures represent the weight of coagulable protein in grammes present in the various flasks. Each flask contained 20 c.c. of the protein solution.

The period of incubation varied from 8-24 days.

\begin{tabular}{|c|c|c|c|c|c|}
\hline \multirow{2}{*}{\multicolumn{2}{|c|}{ Organism examined }} & \multicolumn{2}{|c|}{ Serum-protein } & \multicolumn{2}{|c|}{ Egg-albumin } \\
\hline & & $1 \longdiv { \text { glucose } }$ & 2 & 1 & 2 \\
\hline Control (1) ... & $\ldots$ & $0.0942^{*}$ & $0 \cdot 1097$ & $0 \cdot 1488$ & 0.0944 \\
\hline " (2) ... & $\ldots$ & 0.0993 & $0 \cdot 1115$ & $0 \cdot 1500$ & 0.0944 \\
\hline B. coli communis & $\ldots$ & $0 \cdot 1008$ & $0 \cdot 1084$ & $0 \cdot 1470$ & 一 \\
\hline \multicolumn{2}{|c|}{ B. enteritidis Gaertner } & 0.0963 & $0 \cdot 1084$ & $0 \cdot 1455$ & - \\
\hline B. proteus $\quad \ldots$ & $\ldots$ & $0 \cdot 1010$ & - & $0 \cdot 1480$ & - \\
\hline B. pyocyaneus & $\ldots$ & 0.0992 & $0 \cdot 1083$ & $0 \cdot 1492$ & 0.0964 \\
\hline \multicolumn{2}{|c|}{ Staphylococcus aureus } & $0 \cdot 1013$ & $0 \cdot 1076^{*}$ & $0 \cdot 1507$ & - \\
\hline Gonococcus ... & $\cdots$ & 0.0972 & - & - & 一 \\
\hline \multicolumn{2}{|c|}{ Period of Incubation } & 12 days & 24 days & 14 days & 8 days \\
\hline
\end{tabular}

\section{TABLE VI.}

The action of bacteria on solutions containing serum-protein, salts, and various non-coagulable nitrogenous substances.

In all cases the initial reaction of the medium was as nearly as possible neutral. Control experiments were always made.

The figures indicate the weight of coagulable protein present in the various flasks. The period of incubation varied from 9-28 days.

Each flask contained 20 c.c. of the solution.

\begin{tabular}{|c|c|c|c|c|c|c|c|}
\hline \multirow{2}{*}{\multicolumn{2}{|c|}{ Organism examined }} & \multirow{3}{*}{$\begin{array}{c}\text { A } \\
\text { Alkaline }\end{array}$} & \multirow{2}{*}{$\underset{\substack{\text { Protein } \\
\text { peptone-broth } \\
\text { neutral }}}{\text { A }}$} & \multicolumn{2}{|c|}{$\begin{array}{l}\mathbf{C} \\
\text { Serum-prot.+ filtr.+ }\end{array}$} & \multicolumn{2}{|c|}{$\underset{\text { Horse-serum }}{\mathbf{E}}$} \\
\hline & & & & $\overline{1}$ & 2 & 1 & 2 \\
\hline \multirow{2}{*}{$\begin{array}{cc}\text { Control (1) } & \ldots \\
, & \text { (2) } \ldots\end{array}$} & $\ldots$ & & $0 \cdot 1470^{*}$ & 0.0780 & $0 \cdot 1109$ & $0 \cdot 1884$ & 0.3563 \\
\hline & $\ldots$ & 0.0860 & $0 \cdot 1519$ & 0.0776 & Lost & $0 \cdot 1806$ & $0 \cdot 3507$ \\
\hline \multicolumn{2}{|l|}{ B. coli communis } & - & $0 \cdot 1554$ & 0.0778 & - & $0 \cdot 1710$ & 0.3485 \\
\hline \multicolumn{2}{|c|}{ B. enteritidis Grertner } & 0.0948 & $0 \cdot 1569$ & $0 \cdot 0792$ & $0 \cdot 1120$ & $0 \cdot 1758$ & $0.3469^{*}$ \\
\hline B. pyocyaneus & $\cdots$ & 0.0906 & $0 \cdot 1565$ & 0.0542 & $0 \cdot 1130$ & $0 \cdot 1640$ & 0.3558 \\
\hline B. proteus ... & $\ldots$ & 0.0527 & - & 0.0295 & - & $0 \cdot 1322$ & $0 \cdot 2986$ \\
\hline \multicolumn{2}{|c|}{ Staphylococcus aureus } & - & - & 0.0738 & - & $0 \cdot 1906$ & - \\
\hline Gonococcus ... & $\ldots$ & - & - & - & $0 \cdot 1102$ & - & - \\
\hline \multicolumn{2}{|c|}{ Period of Incubation } & - & 9 days & 10 days & 17 days & 9 days & 28 days \\
\hline
\end{tabular}




\section{TABLE VII.}

The action of bacteria on solutions containing egg-albumin, salts and various non-coagulable nitrogenous substances.

In all cases the initial reaction of the medium was as nearly as possible neutral. Control experiments were always made.

The figures indicate the weight of coagulable protein in grammes present in the various flasks. The period of incubation varied from 6-10 days.

Each flask contained 20 c.c. of the solution.

A

Organism examined

Control (1)

(2) $\ldots$

B. coli communis ...

$B$. enteritidis Gaertner

B. pyocyaneus $\quad$...

B. proteus ...

Staphylococcus aureus...

Period of Incubation

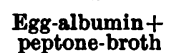
peptone-broth

$0 \cdot 1923$

$0 \cdot 1902$

$0 \cdot 1968$

$0 \cdot 1918$

$0 \cdot 1861$

-

$0 \cdot 1938$

6 days
B

Egg-albumin +

$0 \cdot 1209$

$0 \cdot 1162$

$0 \cdot 1210$

$0 \cdot 1199$

0.1200

-

0.1188

6 days

C

Egg-albumin +
fltered-serum

0.1392

$0 \cdot 1406$

$0 \cdot 1419$

$0 \cdot 1396$

$0 \cdot 1592$

$0 \cdot 1042$

\section{REFERENCES.}

Bienstock (1899). Untersuchungen über die Aetiologie der Eiweissfäulnis. Arch. f. Hygiene, xxxvi. 335.

MarTin, C. J. (1896). Separation of colloids and crystalloids by filtration. Journ. of Physiol. xx. 364.

Martin, W. B. M. (1910). The Isolation of the Gonococcus and its Differentiation from Allied Organisms. Journ. Pathol. and Bacteriol. xv. 76.

RetTaer, L. F. (1906-7). Studies on Putrefaction. Journ. of Biol. Chem. II. 71. (1908). Further Studies on Putrefaction. Ibid. Iv. 45. 